\title{
Histological Study on the Diameter of the Acini of the Human Prostate Gland - A Postmortem Study
}

\author{
Rukshana Ahmed ${ }^{1}$, Shamim Ara $^{2}$, Abu Sadat Mohammad Nurunnabi ${ }^{1}$, Sabiha Mahbub ${ }^{3}$, Abdul
} Alim $^{4}$, Sunjida Shahriah ${ }^{5}$

\begin{abstract}
Context: Pathological process in the prostate gland occurs commonly in association with aging and includes inflammation, atrophy, hyperplasia and carcinoma. Detailed histologic knowledge will help urologists and pathologists to adopt appropriate plan for diagnosis and treatment of prostatic disease.
\end{abstract}

Study design: Descriptive type of study.

Place and period of study: Department of Anatomy, Dhaka Medical College, Dhaka from August 2006 to June 2007.

Materials: 70 post mortem human prostate glands were collected from unclaimed dead bodies that were under examination in the morgue of Department of Forensic Medicine, Dhaka Medical College, Dhaka.

Method: The samples were divided into three age groups i.e. group A (10-20 years), group B (21-40 years), group C (41-70 years). Histological study was carried out on relatively 29 fresh samples.

Result: The mean $\pm S D$ diameter of acini in central zone was $0.29 \pm 0.04 \mathrm{~mm}$ in group $A, 0.40 \pm 0.04 \mathrm{~mm}$ in group $B$ and $0.43 \pm 0.09 \mathrm{~mm}$ in group $C$ and the mean $\pm S D$ diameter of acini in peripheral zone was $0.22 \pm 0.02$ $\mathrm{mm}$ in group $A, 0.26 \pm 0.05 \mathrm{~mm}$ in group $B$ and $0.30 \pm 0.06 \mathrm{~mm}$ in group $C$. Statistically significant positive correlation $(P<0.001)$ was found between age and the diameter of acini of the prostate gland.

Conclusion: There was change in diameter of prostatic acini in relation to age.

Key words: Prostate, histology, acini, diameter.

Introduction:

The prostate is the largest accessory sex gland of the male reproductive system ${ }^{1}$. It is a collection of 30-50 branched tubuloalveolar glands ${ }^{2}$. It was found that central zone was markedly different in histologic appearance from peripheral zone. The acinar tissue of the central zone consisted of large spaces of irregular contour. Peripheral zone was composed of small, round regular acini with smooth walls ${ }^{3}$. The proposed biologic difference

1. Lecturer, Department of Anatomy, Dhaka Medical College, Dhaka.

2. Professor and Head, Department of Anatomy, Dhaka Medical College, Dhaka.

3. Assistant Professor, Department of Anatomy, Tairunnessa Memorial Medical College, Gazipur.

4. Anaesthetist, Modhupur Upazila Health Complex, Tangail.

5. Assistant Professor, Department of Anatomy, Chattagram Ma-O-Shishu Hospital \& Medical College, Chittagong.

Correspondence: Dr. Rukshana Ahmed between central and peripheral zones could be important for understanding prostatic disease, since carcinoma has been reported to arise commonly in the peripheral zone ${ }^{4}$. Cancer of the prostate is the third most common type of cancer among males ${ }^{5}$. According to the Gleason system, prostate cancers are stratified into 5 grades on the basis of glandular patterns and degree of differentiation ${ }^{6}$. Since the early 1990 s, new screening test and improved treatments have been associated with dramatic shifts in the incidence, stage at diagnosis, and mortality of this disease. Major advances in molecular biology and epidemiology have provided new insights into the etiology and biology of prostate cancer. These developments promise to transform our understanding of this disease and will likely lead to new and better ways to prevent and treat prostate cancer in the foreseeable future ${ }^{7}$. 
Materials and Methods:

The samples of human prostate were collected from unclaimed dead bodies that were under examination in the Morgue of the Department of Forensic Medicine of Dhaka Medical College, Dhaka from August 2006 to April 2007.

The collected samples were divided into three groups (according to Begum ${ }^{8}$ ).

Table-I

Age distribution in different group

\begin{tabular}{lcc}
\hline Group & Age in years & No of samples \\
\hline A & $10-20$ & 9 \\
B & $21-40$ & 32 \\
C & $41-70$ & 29 \\
\hline
\end{tabular}

\section{Procedure of Histological Study}

For the histological study, from group A, B \& C 9, $10 \& 10$ samples were taken respectively.

\section{A. Preparation of section:}

Taking the bisected prostate gland, a coronal section was made along the ejaculatory duct up to the base of the verumontanum. An oblique coronal section was also made along the proximal urethral segment which helped in taking out a wedge shaped piece containing central zone (described by $\mathrm{McNeal}^{4}$ ). From this wedge shaped tissue a $4 \mathrm{~mm}^{3}$ piece was taken for histological study. For studying the peripheral zone, two parallel transverse cuts were made about $4 \mathrm{~mm}$ apart and perpendicular to the direction of the distal urethral segment. Thus a large piece of tissue was obtained from which a 4 $\mathrm{mm}^{3}$ small piece was taken.

\section{B. Preparation of the slide:}

Tissue blocks were fixed in $10 \%$ formol saline in a plastic container. The tissue were washed in running tap water, dehydration was done with ascending grades of alcohol, cleared with xylene, infiltrated and embedded in paraffin. Paraffin blocks were cut at $5 \mathrm{~mm}$ thickness and were stained with routine Harris' Haematoxylin and Eosin (H \& E) stain.

\section{Measurement of diameter of acini:}

Acini were not of perfectly spherical in contour. Some were roughly round or oval or polygonal in shape. So it was somewhat difficult to measure the actual diameter. To overcome such type of drawback, the number of ocular micrometer divisions was read out from near to remote margins of the acini and measurements were taken twice for each acini, one along the maximum diameter and another at perpendicular to the first one. Then the number of micrometer divisions were multiplied by the correlation factor derived earlier keeping the magnification constant at $10 \times 10$. Measurement of acini was carried out for central and peripheral zone. The diameter of acini was calculated as follows (according to Begum ${ }^{8}$ ).

\section{Diameter of acini $=($ Maximum diameter + perpendicular diameter $) \div 2$}

The stage micrometer calibration was focused under the objective to be used and the ocular micrometer calibration was superimposed on them in such a way that starting mark on the ocular micrometer matched exactly with a starting mark on the stage micrometer. Then the marker on the stage and ocular micrometer that correspond to each other most closely were noted. In this way determination of how many of the smallest division of the ocular micrometer corresponds to how many smallest division of the stage micrometer was done.

\section{Results:}

In the present study, the mean $\pm S D$ diameter of acini in central zone was $0.29 \pm 0.04 \mathrm{~mm}$ in group $A$, $0.40 \pm 0.04 \mathrm{~mm}$ in group $B$ and $0.43 \pm 0.09 \mathrm{~mm}$ in group C (Table-II, Fig. 1). The highest mean was found in group $C$ and lowest mean was found in group A. Mean difference in diameter of acini between group $A$ and group $B$, group $A$ and group $C$ were statistically significant $(P<0.001)$. The mean difference between group $B$ and group $C$ was not statistically significant $(P>0.10)$. Positive correlation was found between age and diameter of acini in central zone which was statistically significant $(r=$ $+0.744, \mathrm{P}<0.001$ ) (Fig. 2). 
The mean $\pm S D$ diameter of acini in peripheral zone was $0.22 \pm 0.02 \mathrm{~mm}$ in group $A, 0.26 \pm 0.05 \mathrm{~mm}$ in group $B$ and $0.30 \pm 0.06 \mathrm{~mm}$ in group C (Table-II, Fig.-1). The highest mean diameter in peripheral zone was found in group $C$ and lowest was found in group A. In the peripheral zone, the mean difference in diameter of acini between group $A$ and group $B$ was statistically significant $(P<0.05)$. Mean difference between group $A$ and group $C$ was also statistically significant $(P<0.001)$. Mean difference between group $B$ and group $C$ was not statistically significant $(P>0.05)$. Positive correlation was found between age and diameter of acini in peripheral zone which was statistically significant $(r=+0.662, P<$ 0.001) (Fig.-2).

Table-II

Diameter of acini in the central and peripheral zone of prostate in different study group

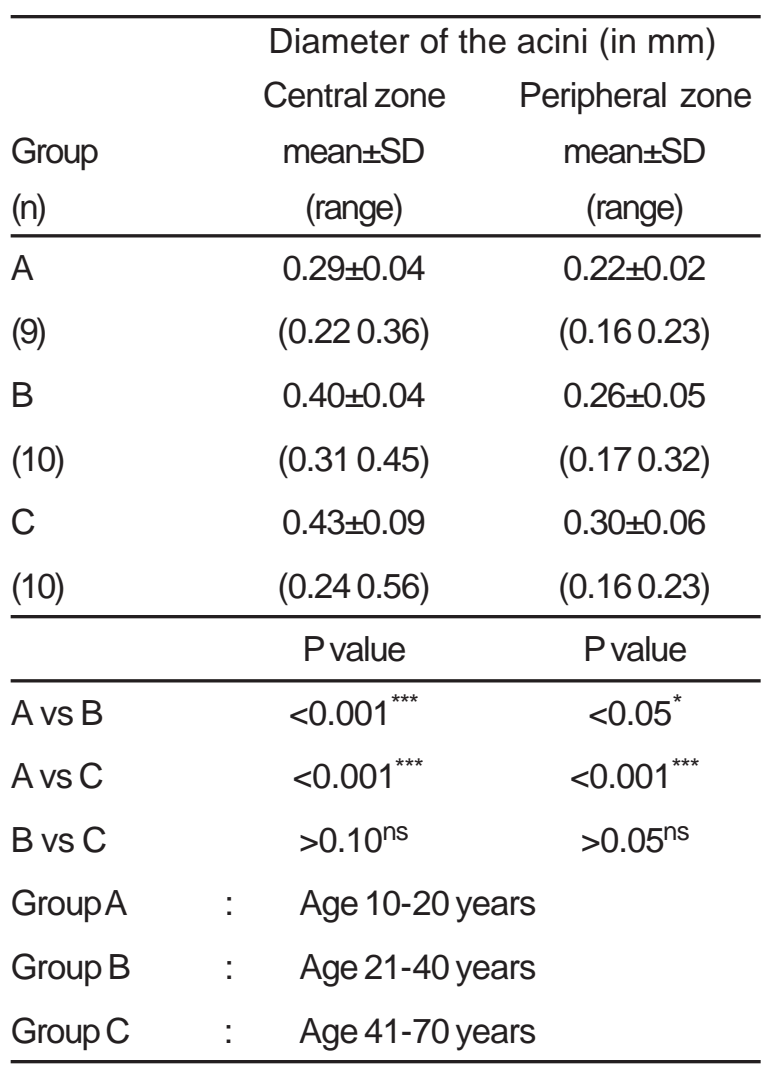

Statistical analysis was done by ANOVA (multiple comparison), ns $=$ not significant, ${ }^{\star}{ }^{\star \star \star}=$ significant

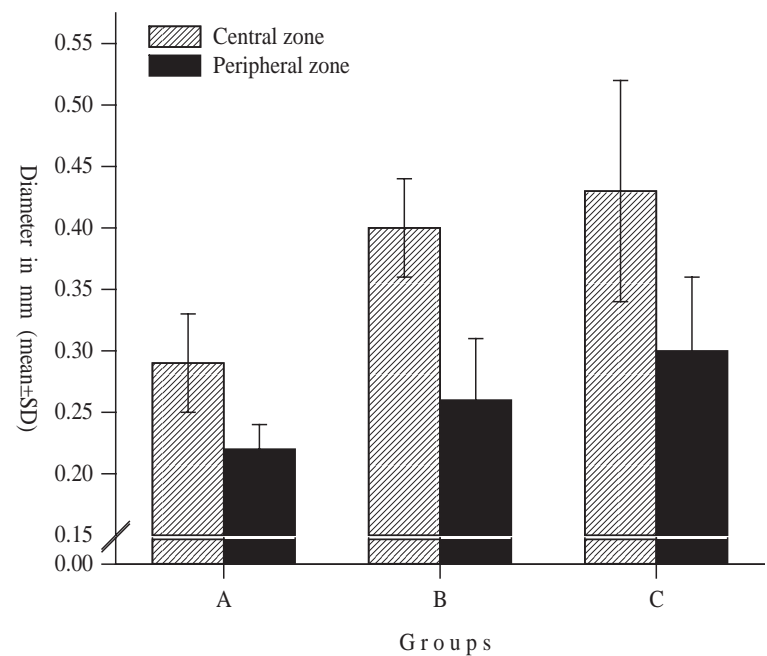

Group A : Age 10-20 years

Group B : Age 21-40 years

Group C : Age 41-70 years

Fig. 1: Diameter of acini in the central and peripheral zone of prostate in different study group.

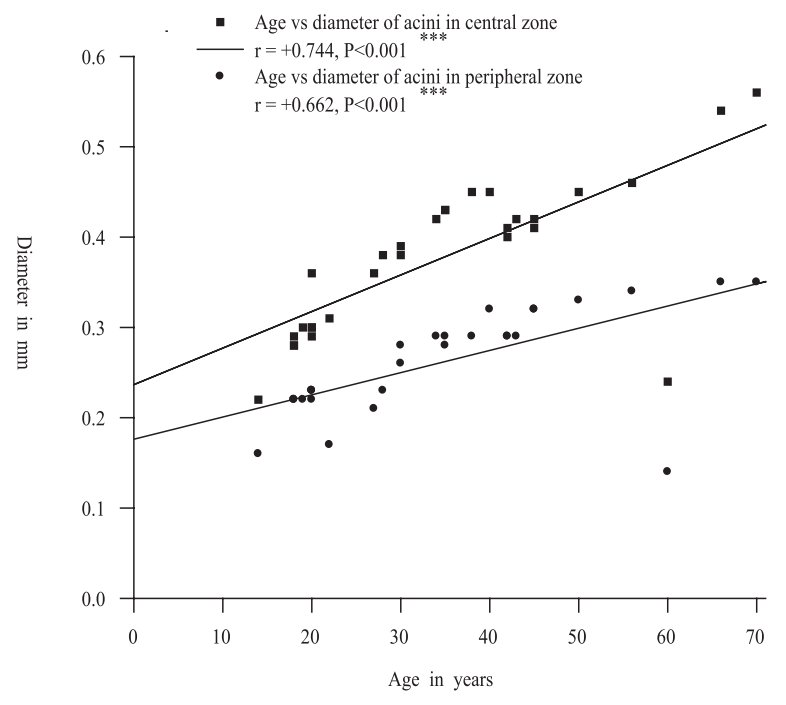

Fig.-2: Scatter diagram showing relationship between age and diameter of acini in the central and peripheral zone of prostate.

\section{Discussion:}

In the present study, the mean \pm SD diameter of acini in the central zone was $0.29 \pm 0.04 \mathrm{~mm}$ in group $A$, $0.40 \pm 0.04 \mathrm{~mm}$ in group $B$ and $0.43 \pm 0.09 \mathrm{~mm}$ in group $C$. In the peripheral zone the mean $\pm S D$ diameter of acini was $0.22 \pm 0.02 \mathrm{~mm}$ in group $A$, $0.26 \pm 0.05 \mathrm{~mm}$ in group $B$ and $0.30 \pm 0.06 \mathrm{~mm}$ in group 
C. $\mathrm{Khan}^{9}$ observed that the mean \pm SD diameter of acini in the central zone was $0.30 \pm 0.01$ in group $A$, $0.24 \pm 0.03$ in group $B$ and $0.31 \pm 0.02 \mathrm{~mm}$ in group $C$. In the peripheral zone he found that mean $\pm S D$ diameter of acini was $0.23 \pm 0.01 \mathrm{~mm}$ in group $A$, $0.25 \pm 0.01 \mathrm{~mm}$ in group $B$ and $0.27 \pm 0.01 \mathrm{~mm}$ in group $C$. These findings are almost similar to the present findings.. Begum ${ }^{8}$ found that in the central zone ,the diameter of acini were $0.30 \pm 0.03 \mathrm{~mm}$ in group $A, 0.41 \pm 0.01 \mathrm{~mm}$ in group $B$ and $0.48 \pm 0.01$ $\mathrm{mm}$ in group $\mathrm{C}$. In the peripheral zone she found that diameter of acini in group $A$ was $0.22 \pm 0.02$, in group B was $0.29 \pm 0.01$ and in group $C$ was $0.32 \pm 0.01$. This finding corresponds to the present findings.

\section{Acknowledgement:}

We express our gratitude to the authority of Health, Nutrition and Population Sector Programme (HNPSP) of Directorate General of Health Services (DGHS), Bangladesh and Dhaka Medical College, Dhaka for the research grant.

\section{References:}

1. Ross MH, Pawlina W. Histology: a text and atlas with correlated cell and molecular biology. 5th ed. Baltimore: Lippincott Williams \& Wilkins; 2006. p. 752.

2. Junqueira LC, Carneiro J. Basic histology. 11th ed. California: Lange; 2005. p. 418.

3. McNeal JE. Anatomy of the prostate : a historical survey of divergent views. Prostate. 1986; (1): 3-13.

4. McNeal JE. The zonal anatomy of the prostate. Prostate 1981; 2: 35-49.

5. Salam MA. Principles and practice of urology. Dhaka: MAS Publication; 2002. p. 665-94.

6. Kumar V, Abbas AK, Fausto N. eds. Robbins and Cotran pathologic basis of disease. 7th ed. New Delhi: W B. Saunders; 2005. p. 1053.

7. Reiter RE, Dekernion JB. eds. Campbell's Urology. 8th ed. Philadelphia: W B. Saunders; 2002. p. 3003.

8. Begum S. An anatomical study of age changes of prostate in Bangladeshi people [thesis]. Dhaka: University of Dhaka; 1990.

9. Khan SH. Gross and histomorphological study of the prostate: an age perspective in Bangladeshi males [thesis]. Dhaka: University of Dhaka; 1995. 